\title{
Evaluation of Pre-miRNA-146a rs2910164 Variations and sCD40 Ligand in Egyptian Patients with Rheumatoid Arthritis
}

\author{
FATMA H. ABDELRAOUF, M.D. ${ }^{\mathbf{1}}$; HOIYDA A. ABDEL RASOL, M.D. ${ }^{\mathbf{2}}$; WALAA G. HOZAYEN, M.D. $^{\mathbf{3}}, \mathbf{4}^{\mathbf{4}}$; \\ HANAN HUSSEIN, M.D. ${ }^{5}$; ENGY EL KHATEEB, M.D. ${ }^{1}$; WALID BAKEER, M.D. ${ }^{6}$; \\ GOMAA ABDEL RAZEK, M.D. ${ }^{7}$; WAEL M. ABDEL KHALEK, M.D. ${ }^{8}$ and HEND H. TAMIM, M.D. ${ }^{1}$ \\ The Department of Clinical \& Chemical Pathology, Faculty of Medicine, Cairo University, Cairo ${ }^{\mathbf{1}}$, \\ The Department of Clinical Pathology, Faculty of Medicine, Fayoum University, Fayoum 2 , \\ The Department of Chemistry Division of Biochemistry, Faculty of Science ${ }^{3}$ and The Department of Biotechnology \& \\ Life Sciences, Faculty of Postgraduate Studies for Advanced Sciences (PSAS) ${ }^{4}$, Beni-Suef University, Beni-Suef, \\ The Department of Rheumatology \& Rehabilitation, Faculty of Medicine, Cairo University, Cairo \\ The Department of Microbiology \& Immunology, Faculty of Pharmacy, Beni-Suef and Nahda Universities, Beni-Suef 6 \\ The Department of Cardiology, Faculty of Medicine, Fayoum University, Fayoum ${ }^{7}$ and The Department of Medical Biochemistry, \\ Faculty of Postgraduate Studies for Advanced Sciences (PSAS), Beni-Suef University, Beni-Suef ${ }^{\boldsymbol{8}}$, Egypt
}

\begin{abstract}
Background: Patients with Rheumatoid Arthritis (RA) are at greater risk of developing Cardiovascular (CV) events with higher rate of subsequent mortality. MicroRNAs (miRNAs) such as MiR-146a are thought to have an important role in the pathogenesis of RA. CD40-CD40L interaction is potentially involved in atherogenesis and plaque rupture in RA, it can be a risk factor in development of accelerated vascular complications in RA patients.
\end{abstract}

Aim of Work: Our aim is to evaluate the level of sCD40L, investigate the genetic variations (polymorphisms) in premiRNA-146a rs2910164 in a cohort of Egyptian RA patients and detect their possible relation to $\mathrm{CV}$ risk in RA.

Methods: 108 RA patients were enrolled in our study and were divided into 2 groups according to presence and absence of CV risk along with 49 controls. Genotyping of premicroRNA-146a rs2910164 polymorphism was done by TaqMan real-time PCR and serum sCD40L levels were measured using human soluble CD40L ELISA assay.

Results: $\mathrm{SCD} 40 \mathrm{~L}$ concentration was significantly lower in RA patients without $\mathrm{CV}$ risk and RA patients with $\mathrm{CV}$ risk when compared to control group ( $p<0.001)$, but there was no statistically significant difference when comparing both patients' groups $(p=0.5)$. The genotype and allele frequencies of pre-microRNA-146a rs2910164 did not show a statistically significant difference between the studied groups. When comparing RA group without $\mathrm{CV}$ risk, RA group with $\mathrm{CV}$ risk and control group, GG genotype was $41.8 \%, 39.6 \%$ and $32.7 \%$, GC was $40 \%, 49.1 \%$ and $51 \%$ and $\mathrm{CC}$ was $18.2 \%$, $11.3 \%$ and $16.3 \%$, respectively. G allele frequency in RA without $\mathrm{CV}$ risk group, $\mathrm{RA}$ with $\mathrm{CV}$ risk group and control group was $35.2 \%, 35.2 \%$ and $29.5 \%$ and $\mathrm{C}$ allele frequency was $34.7 \%, 31.4 \%$ and $33.9 \%$, respectively.

Correspondence to: Dr. Engy El-Khateeb, E-Mail: engy.alkhatib@kasralainy.edu.eg
Conclusion: Pre-miRNA-146a rs2910164 gene variations were not associated with RA and does not increase the susceptibility to cardiovascular disease. Low serum levels of sCD40L were detected in RA patients irrespective of the presence of cardiovascular risk. Evaluating sCD40L in patients not receiving any treatment and comparing them with posttreatment levels is recommended.

Key Words: Rheumatoid Arthritis $-s C D 40 L-$ Pre-miRNA$146 a$ - rs2910164 - Real-time PCR - ELISA.

\section{Introduction}

RHEUMATOID Arthritis (RA) is a chronic inflammatory autoimmune disease affecting up to $1.0 \%$ of the population worldwide [1]. It is characterized by chronic synovial inflammation leading to synovial lining cell hyperplasia [2], progressing to joint destruction, functional disability, and sometimes death [3]. The risk of Cardiovascular Disease (CVD) in patients with RA is two times higher than age-and sex-matched persons and is seen as common cause of death due to a process of accelerated atherosclerosis [4].

Pathogenesis of atherosclerosis is attributed to activation of inflammatory pathways, thereby suggesting that atherosclerosis and RA share common pathogenesis. Both immune dysregulation and a systemic inflammatory environment contribute to vascular inflammatory damage that occur in RA [4-6].

CD40L (also known as CD40 ligand or CD 154) is a $39 \mathrm{kDa}$ transmembrane protein with specific 
importance in T-cell dependent humoral immune responses. It acts as a ligand for CD40, a member of the TNF-receptor superfamily. Soluble CD40L (sCD40L) has been related to various immune and inflammatory diseases such as Systemic Lupus Erythematosus (SLE), RA, and Sjogren's syndrome disease activity [7]

When CD40 interacts with its ligand (CD40L) on $\mathrm{T}$ cells, it works as a transmembrane signal transducer stimulating intracellular kinases and transcription factors, leading to inflammatory reactions, production of inflammatory cytokines, expression of adhesion molecules, production of autoantibodies, as well as activation of many other inflammatory processes, all of which boost disease development [7].

It has also been observed that CD40-CD40L interaction is believed to be involved in atherogenesis and plaque tear in RA. CD40L is expressed on atherosclerotic plaques' constituting cells such as monocytes, macrophages, endothelial cells, and smooth muscle cells [8]. In addition, CD40-CD40L interaction may motivate matrix metalloproteinases expression, degrading components of atherosclerotic plaques and encouraging their rupture. This can explain pathogenesis of acute thrombotic CV events and sudden death in RA [9].

sCD40L may represent the biological link between autoimmune diseases and atherosclerosis. It can be an essential risk factor in the development of accelerated vascular complications defined in RA patients [5].

The role of microRNAs (miRNAs) in the pathogenesis of RA, has been an interest area of research, posing as a potential disease biomarker [10]. miRNAs regulate gene expression at post-transcriptional level, and are associated with various biological events such as cell growth, cell differentiation, apoptosis, carcinogenesis, and autoimmune arthritis development [11]. Polymorphisms in miRNA genes may change a wide range of biological mechanisms by affecting the processing and/or target selection of miRNAs [10,11]

MiR-146a was suggested to play an important role in RA development [12-14]. It is located on human chromosome $5 \mathrm{q} 34$ and relates to immune regulation, inflammatory signalling pathway, because it can regulate the expression of IL-1 Receptor-Associated Kinase (IRAK1) and IRAK2 and targets TNF Receptor-Associated Factor 6 (TRAF6) [15]. MiR-146a seems to be a regulator in RA development by driving a negative feedback mechanism to inhibit excess inflammation [16]. Studies have evaluated the association of pre-miRNA-146a rs2910164 with susceptibility to some autoimmune disease including RA and SLE with conflicting results [17-20].

The aim of the current study is to evaluate the level of sCD40L and investigate the genetic polymorphisms in pre-miRNA-146a rs2910164 in a cohort of Egyptian RA patients and detect their possible relation to cardiovascular risk in RA.

\section{Patients and Methods}

\section{Study population:}

A total of 108 RA patients diagnosed according to the 2010 ACR-EULAR classification criteria for RA were enrolled in our study [21]. Two groups were identified: A group having RA with cardiovascular risk (53 patients) and a group having RA without cardiovascular risk (55 patients). The patients with cardiovascular risk were selected upon the following criteria (age, obesity, diabetes mellitus, hypertension, dyslipidemia, smoking and positive family history). They were recruited from cases admitted and followed-up in Rheumatology and Rehabilitation Department, Kasr Al-Ainy Hospitals, Cairo University, Egypt (from June 2017 to June 2018). Any patient diagnosed with other autoimmune disease, chronic illness, or comorbidities was excluded from the study.

Forty-nine healthy Egyptian subjects age and sex matched to cases with no known past or family history of RA, any associated autoimmune diseases or joint diseases were taken as a control group.

All patients underwent an initial evaluation that included a medical history and physical examination. Erythrocyte Sedimentation Rate (ESR), C Reactive Protein (CRP), rheumatoid factor (RF) and anti-Cyclic Citrullinated Protein (anti-CCP) results were obtained from patients' history files. All patients were receiving Disease Modifying Anti-rheumatic Drugs (DMARD) as a regular therapy.

The study was accomplished in accordance with the Code of Ethics of the World Medical Association (Declaration of Helsinki), and after the acceptance of the Local Ethical Committee of Cairo University. Informed consent was obtained from all study subjects after the nature of the study was explained.

\section{Measure of disease activity:}

Disease activity was measured using a RA Disease Activity Score to determine that comprises 28 joint counts (DAS28) [22]. Scores were calcu- 
lated using a DAS28 calculator and were based on the 28 tender and swollen joint counts, global health measurement and the degree of inflammation (including ESR and CRP). Patients with a DAS28 greater than 5.1 were defined as having high disease activity, those with less than 3.2 as low disease activity, and those with less than 2.6 as in remission.

Genotyping of pre-microRNA-146a rs2910164 polymorphism by TaqMan real-time polymerase chain reaction:

Two milliliters of venous blood were collected in a sterile vacutainer containing Ethylene Diamine Tetra Acetate (EDTA) as an anticoagulant for DNA extraction and genotyping by real time PCR, stored at $-20^{\circ} \mathrm{C}$.

Genomic DNA was separated using the GeneJET Whole Blood Genomic DNA Purification Mini Kit \#K0781, (Thermo Fisher Scientific Inc, California, USA), as stated by the manufacturer's guidelines. DNA concentration was measured by using the Nanodrop ND-1000 (NanoDrop Technologies, Inc, Thermo Fisher Scientific, DE). For investigation of rs2910164, real-time Polymerase Chain Reaction (PCR) allelic discrimination was accomplished on Step-One Real-Time PCR (Applied Biosystems, Foster City, CA) by using standard TaqMan genotyping assays according to the manufacturer's guidelines.

In brief, probes, primers, and TaqMan universal PCR Master Mix were obtained from Applied Biosystems. A reaction solution of $25 \mathrm{~mL}$ contained 1.25mL TaqMan Genotyping Assay mix (consisting of 20X Mix of unlabeled PCR primers and TaqMan minor groove binder probes, FAMTM and VIC® dye labeled), $12.5 \mathrm{~mL}$ of TaqMan Universal PCR Master Mix (2X), 25ng of genomic DNA and water was added to complete whole volume to $25 \mathrm{uL}$. The PCR cycle consisted of pre-PCR read at $60^{\circ} \mathrm{C}$ for 30 seconds, holding stage at $95^{\circ} \mathrm{C}$ for 10 minutes, 50 cycles of denaturing at $92^{\circ} \mathrm{C}$ for 15 seconds, annealing $60^{\circ} \mathrm{C}$ for 1 minute 30 seconds and postPCR read at $60^{\circ} \mathrm{C}$ for 30 seconds. After PCR amplification, reading of an endpoint plate was accomplished using an Applied Biosystems real-time PCR system. The Sequence Detection System Software uses the fluorescence measurements made during the plate read to plot fluorescence values built on the signals from each well. The plotted fluorescence signals point out to which of alleles are in each sample.

\section{Measurement of serum sCD4OL levels:}

Two $\mathrm{mL}$ of venous blood were collected in plain centrifuge tube, allowed to clot for at least
30 minutes, and centrifuged at $1000 \mathrm{x} \mathrm{g}$ for 15 minutes. Sera of patients were separated in other tubes and stored at $-20^{\circ} \mathrm{C}$.

The serum sCD40L levels were measured using human soluble cluster of differentiation 40 ligand (sCD40L) enzyme-linked immunosorbent assay kit according to the manufacturer's instructions (SinoGeneclon Co., Ltd, China Catalogue: SG10126). The concentration of SCD40L in the samples was then calculated by comparing the O.D. of the samples to the standard curve.

\section{Statistical analysis:}

Statistical analyses were accomplished using the SPSS (statistical package for social science) version 17. Data were undergoing to KolmogorovSmirnov test to locate the distribution and method of analysis [23]. Data were normally distributed, quantitative variables are presented as mean $\pm \mathrm{SD}$, and the comparisons between groups were performed using ANOVA test. Categorical variables were given as percentages. A chi-square test was used to compare the gender, CRP, RF, Anti-CCP, allele frequency and genotype frequency. A two tailed $p$-value of less than 0.05 were considered as statistically significant and less than 0.001 were considered as high statistically significant.

\section{Results}

Demographic data and clinical characterisation of the study groups:

Our study group consisted of 108 RA patients (53 patients with CV risk and 55 patients without CV risk) compared to 49 healthy control subjects. Demographic data of the studied subjects as well as relevant clinical and laboratory investigations of the patients' groups are summarized in (Tables $1,2)$. There was no statistically significant difference between both groups and control as regards age or $\operatorname{sex}(p 0.1$ and 0.2 respectively). There were high statistically significant differences between each of the patients' groups and the control group as regards ESR (first and second hours) $(p<0.001)$. There was no statistically significant difference seen when comparing RA group without CV risk and RA group with CV risk regarding DAS score, $\mathrm{CRP}, \mathrm{RF}$ and anti-CCP $(p 0.2,0.3,0.4$ and 0.8 respectively).

\section{sCD4OL in the studied groups:}

The mean value $( \pm \mathrm{SD})$ for $\mathrm{SCD} 40 \mathrm{~L}$ in RA without CV risk group was $200.5 \pm 124.9 \mathrm{ng} / \mathrm{L}$, and in RA with $C V$ risk group the mean value $( \pm S D)$ was $168.7 \pm 83.2 \mathrm{ng} / \mathrm{L}$ whereas in control group the mean 
value $( \pm$ SD) was $297.9 \pm 148.1 \mathrm{ng} / \mathrm{L}$. The study revealed that $\mathrm{SCD} 40 \mathrm{~L}$ concentration was significantly lower in RA patients without $\mathrm{CV}$ risk and RA patients with CV risk when compared to control group $(p<0.001)$, but there was no statistically significant difference when comparing both patients' groups ( $p 0.5)$ (Table 3).

Table (1): Demographic, clinical and laboratory data of the studied participants.

\begin{tabular}{|c|c|c|c|c|}
\hline Characteristics & $\begin{array}{l}\text { Control } \\
\text { group } \\
(n=49)\end{array}$ & $\begin{array}{l}\text { RA patients } \\
\text { without CV } \\
\text { Risk }(n=55)\end{array}$ & $\begin{array}{c}\text { RA patients } \\
\text { with CV } \\
\text { Risk }(n=53)\end{array}$ & $\begin{array}{c}p- \\
\text { value }\end{array}$ \\
\hline Age (years) & $44.7 \pm 6.1$ & $45.4 \pm 10.4$ & $47.5 \pm 7.3$ & $0.2^{*}$ \\
\hline \multicolumn{5}{|l|}{$\operatorname{Sex} N(\%):$} \\
\hline Male & $11(22.4 \%)$ & $6 \quad(10.9 \%)$ & $6 \quad(11.3 \%)$ & $0.1 *$ \\
\hline Females & $38(77.6 \%)$ & $49(89.1 \%)$ & $47(88.7 \%)$ & \\
\hline \multicolumn{5}{|l|}{ Smoking N(\%): } \\
\hline Non-smoker & $45(91.8 \%)$ & $55(100 \%)$ & $50(94.3 \%)$ & $0.1^{*}$ \\
\hline Smoker & $4 \quad(8.2 \%)$ & $0(0 \%)$ & $3 \quad(5.7 \%)$ & $0.1^{*}$ \\
\hline \multicolumn{5}{|l|}{ Disease } \\
\hline \multicolumn{5}{|l|}{ duration years: } \\
\hline Mean \pm SD & & $7.04 \pm 0.95$ & $6.97 \pm 0.96$ & $0.1 *$ \\
\hline DAS28 score & & $4.4 \pm 0.72$ & $4.68 \pm 0.89$ & $0.2^{*}$ \\
\hline \multicolumn{5}{|l|}{ ESR, $\mathrm{mm} / \mathrm{h}:$} \\
\hline 1st hour & $5.4 \pm 0.7$ & $40 \pm 15.4$ & $38.9 \pm 16.9$ & $<0.001 * * \mathbf{a}^{\prime} \mathbf{b}$ \\
\hline 2nd hour & $10.7 \pm 1.3$ & $72.4 \pm 21.9$ & $71.3 \pm 23.1$ & $<0.001 * * \mathbf{a}^{\prime} \mathbf{b}$ \\
\hline
\end{tabular}

RA : Rheumatoid Arthritis.

ESR : Erythrocyte sedimentation rate.

DAS28 : 28-joint Disease Activity Score.

CV : Cardiovascular.

: Non-significant between all groups.

** : Very high significant.

a : Significance between control \& RA group without CV risk.

b : Significance between control \& RA group with CV risk.

Table (2): Comparison of CRP, RF and anti CCP between the two patients' groups.

\begin{tabular}{llll}
\hline $\begin{array}{l}\text { Laboratory } \\
\text { parameter }\end{array}$ & $\begin{array}{c}\text { RA patients } \\
\text { without CV } \\
\text { Risk }(\mathrm{n}=55)\end{array}$ & $\begin{array}{c}\text { RA patients } \\
\text { with CV } \\
\text { Risk (n=53) }\end{array}$ & $p$-value \\
\hline $\begin{array}{l}\text { CRP N (\%): } \\
\text { Negative }\end{array}$ & $31(56.4 \%)$ & $35(66 \%)$ & $0.3^{*}$ \\
Positive & $24(43.6 \%)$ & $18(34 \%)$ & \\
RF N (\%): & $17(30.9 \%)$ & $2(22.6 \%)$ & $0.4^{*}$ \\
Negative & $38(69.1 \%)$ & $41(77.4 \%)$ & \\
Positive & & & $0.8^{*}$ \\
Anti CCP N (\%): & $17(30.9 \%)$ & $18(34 \%)$ & \\
Negative & $38(69.1 \%)$ & $35(66 \%)$ & \\
Positive & & & \\
\hline
\end{tabular}

CRP : C-Reactive Protein.

RF : Rheumatoid Factor.

Anti-CCP : Antibodies to Cyclic Citrullinated Peptides.

$\mathrm{CV}$ : Cardiovascular.

Non-Significant.
Table (3): sCD40L levels in different study groups.

\begin{tabular}{|c|c|c|c|c|}
\hline Variables & $\begin{array}{c}\text { Control } \\
(n=49) \\
\text { Mean } \pm \text { SD } \\
(n g / L)\end{array}$ & $\begin{array}{c}\text { RA without } \\
\text { CV risk } \\
(n=55) \\
\text { Mean } \pm \text { SD } \\
(n g / L)\end{array}$ & $\begin{array}{c}\text { RA with } \\
\text { CV risk } \\
(n=53) \\
\text { Mean } \pm \text { SD } \\
(n g / L)\end{array}$ & $p$-value \\
\hline sCD40L & $297.9 \pm 148.1$ & $200.5 \pm 124.9$ & $168.7 \pm 83.2$ & $\begin{array}{l}<0.001 \text { a,b } \\
0.5 \mathrm{c}\end{array}$ \\
\hline
\end{tabular}

a: Significance between control \& RA without risk.

b: Significance between control \& RA with risk.

c: Significance between RA without risk \& RA with risk.

\section{Pre-microRNA-146a rs2910164 Genotype and} Allele frequency distribution:

Frequency of pre-microRNA-146a rs2910164 genotype and allele frequency among the studied groups are demonstrated in (Table 4). The genotypic and allelic frequencies of pre-microRNA-146a rs2910164 did not display deviation from HardyWeinberg equilibrium suggesting that there was a genetic equilibrium of population joined.

We compared the genotype frequency (GG, CG and CC) as well as allele frequency in rs2910164 between RA without $\mathrm{CV}$ risk group, $\mathrm{RA}$ with $\mathrm{CV}$ risk group and control group. There was no statistically significant difference between the three groups. We found that GG genotype in RA group without CV risk was $23(41.8 \%), \mathrm{GC}$ was $22(40 \%)$ and $\mathrm{CC}$ was $10(18.2 \%)$. In RA group with CV risk, GG was $21(39.6 \%)$, GC was 26 (49.1) and $\mathrm{CC}$ was $6(11.3 \%)$ compared with control group having GG $16(32.7 \%)$, GC $25(51 \%)$ and CC was $8(16.3 \%)$ ( $p$ 0.7). The distribution of the $\mathrm{G}$ allele in $\mathrm{RA}$ without $\mathrm{CV}$ risk group, $\mathrm{RA}$ with $\mathrm{CV}$ risk group and control group was $35.2 \%, 35.2 \%$ and $29.5 \%$ respectively, whereas the $\mathrm{C}$ allele between groups were $34.7 \%, 31.4 \%$ and $33.9 \%$ respectively ( $p 0.4$ and 0.4 respectively) (Table 4 ).

Table (4): Distribution of pre-miRNA-146a (rs2910164) genotypes and allele frequencies in Rheumatoid Arthritis (RA) patients, RA with cardiovascular risk patients and control groups.

\begin{tabular}{lllll}
\hline Genotypes & $\begin{array}{c}\text { Control } \\
(\mathrm{n}=49) \\
\text { No. }(\%)\end{array}$ & $\begin{array}{c}\text { RA without } \\
\text { CV risk } \\
(\mathrm{n}=55) \\
\text { No. }(\%)\end{array}$ & $\begin{array}{c}\text { RA with } \\
\text { CV risk } \\
(\mathrm{n}=53) \\
\text { No. }(\%)\end{array}$ & $\begin{array}{c}p- \\
\text { value }\end{array}$ \\
\hline GG & $16(32.7 \%)$ & $23(41.8 \%)$ & $21(39.6 \%)$ & $0.7^{*}$ \\
CG & $25(51 \%)$ & $22(40 \%)$ & $26(49.1 \%)$ & \\
CC & $8(16.3 \%)$ & $10(18.2 \%)$ & $6(11.3 \%)$ & \\
G allele $(\mathrm{n}=193)$ & $57(29.5 \%)$ & $68(35.2 \%)$ & $68(35.2 \%)$ & $0.4^{*}$ \\
C allele (n=121) & $41(33.9 \%)$ & $42(34.7 \%)$ & $38(31.4 \%)$ & $0.4 *$ \\
\hline *: Non-significant. & & & &
\end{tabular}

There was also no statistically significant difference among the 108 RA patients in genotype frequency when stratified by sex, knee osteoarthri- 
tis, extra articular manifestations, anti-CCP, CRP and $\operatorname{RF}(p 0.08,0.2,0.3,0.09,0.8$ and 0.2 respectively) (Table 5).

Table (5): Comparisons of sex, knee osteoarthritis, anti CCP, $\mathrm{CRP}$ and RF in genotypes among different genotypes.

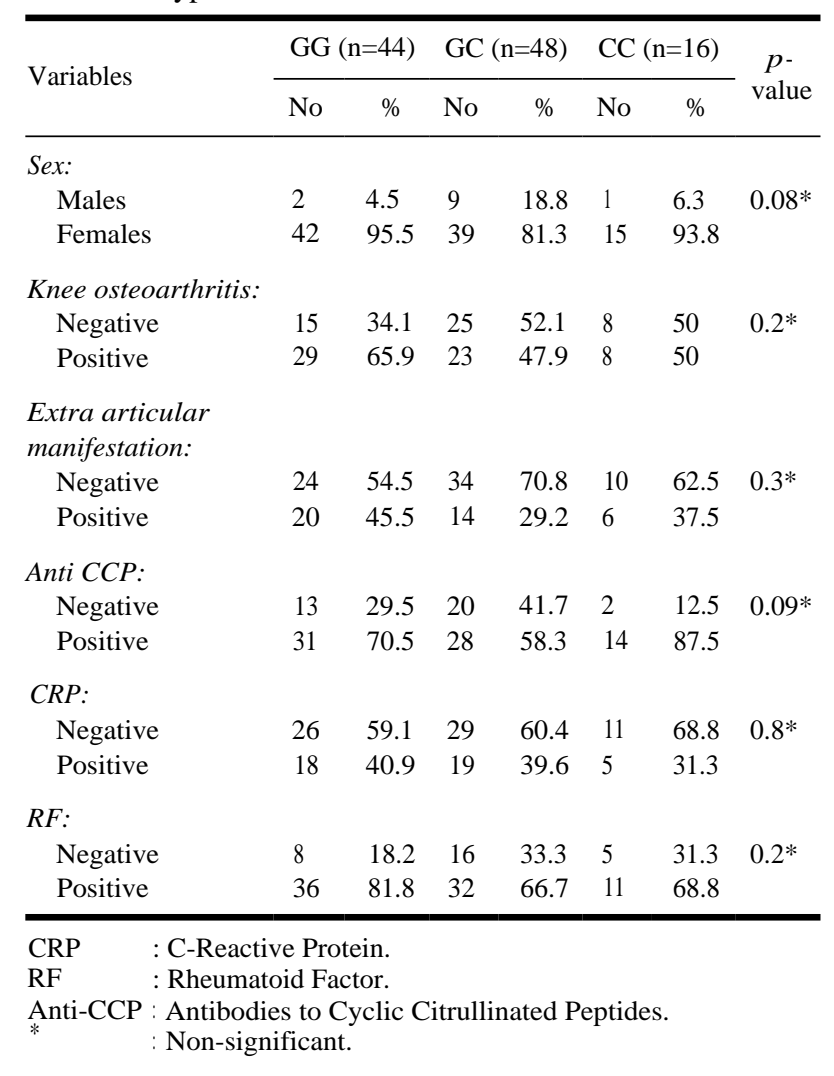

\section{Discussion}

Patients with RA are at greater risk of developing CV events with higher rate of subsequent mortality [3]. Females with RA were found to have more than 2-fold higher risk of developing myocardial infarction compared with women without this pathology [4].

MiRNAs are novel biomarkers for CVD, including coronary artery disease [24]. MiR-146a was proposed to play an important role in RA development, acting as an important regulator in RA development as effectors in driving a negative feedback mechanism to inhibit excess inflammation [16].

It has also been observed that CD40-CD40L interaction is believed to be involved in atherogenesis and plaque rupture in RA, so sCD40L may be the link between autoimmune diseases and atherosclerosis. It can be an essential risk factor in the development of accelerated vascular complications defined in RA patients [5].
The aim of the current study is to evaluate the level of sCD40L and investigate the genetic polymorphisms in pre-miRNA-146a rs2910164 in a cohort of Egyptian RA patients and detect their possible relation to cardiovascular risk in RA.

In our study, by comparing RA patients without $\mathrm{CV}$ risk and those with CV risk, we found no statistically significant difference regarding CRP, RF positivity nor anti-CCP positivity $(p>0.05)$. These results agree with Yang et al., (2011) who found no significant difference between each of RF-positivity and the level of anti-CCP antibody in Han Chinese population with RA [25].

In the present study, mean value of ESR was highly significantly increased in RA patients compared to the control group $(p<0.001)$. This is concordant with previous studies. ESR level is one of the acute phase reactants and indicates the presence of an inflammatory state, such as RA [26,27]

When comparing genotype frequencies of preMiR146a rs2910164 between RA group without $\mathrm{CV}$ risk, RA group with cardiovascular risk and control group, no statistical significance was observed. Similar non-significance was seen when comparing allele frequencies. Our results came in agreement with several studies including the study done by Yang et al., (2011) and Alemán-Ávila et al., (2017) who found that there was no evidence of association between rs2910164 polymorphism and RA [25,28]. Also, El-Shal et al., (2013) showed no significant association between rs2910164 polymorphism in Egyptian RA females and controls regarding risk, severity, and activity [29]. Similar findings were found by Fu et al., (2016) [20].

We compared variable clinical and laboratory parameters as sex, knee osteoarthritis, extraarticular manifestations, anti-CCP, CRP and RF in RA patients with different genotypes and did not find a statistically significant difference among different genotypes. A study by Hu et al., (2019) evaluating rs2910164 polymorphisms among RA patients did not find significant difference between RA and control group. Also, no significant association was found between miR-146a rs2910164 polymorphism with DAS28. However, RA patients with a GG genotype had a greater chance to develop extraarticular manifestations [13].

Several meta-analyses were performed in the previous years and their results were concordant with some findings of our study. One meta-analysis did not find a significant association of miRNA146a polymorphism with an RA risk, however, suggested that GG genotype might increase the 
risk of RA in females, and CC genotype may influence disease activity when evaluated with DAS28 score [12]. A meta-analysis by Xiao et al., (2019) also did not find any relation between miRNA-146a polymorphism and RA [14] . In addition, another meta-analysis showed that there is lack of association between miRNA-146 rs2910164 polymorphism and inflammatory arthritis susceptibility in general population but may be associated with high risk in Middle East [30].

On the other hand, some studies came in contrast with our results. A study on Iranian female patients suggested that rs2910164 is associated with RA susceptibility [31]. Ayeldeen et al., (2018) found that GG genotype as well as the frequency of the $\mathrm{G}$ allele were significantly higher in RA Egyptian patients compared to controls [26]. The discrepancy between these various studies may be partly explained by differences in ancestry between studied populations as well as different study designs and sample sizes.

Furthermore, results from our study showed that $\mathrm{SCD} 40 \mathrm{~L}$ levels in RA patients without $\mathrm{CV}$ risk and RA patients with CV risk group were statistically significantly lower than those in control group, and by comparing both groups of RA patients, we did not find statistically significant difference between them. This is in contrast with some older studies who found that $\mathrm{SCD} 40 \mathrm{~L}$ is high in RA patients [32-34] and Juvenile Idiopathic Arthritis (JIA) [35]

Our patients' groups were on DMARDs treatment. It was notable that DMARD treatment results in great suppression of inflammation, thus reducing the development of atherosclerosis and subsequently CVD. Targeting inflammation with TNF- $\alpha$ inhibitors or methotrexate may have positive cardiovascular effects in RA [36]. The absolute risk of venous thromboembolism was low in RA patients receiving either biologic or nonbiologic DMARDs such as methotrexate [37].

TNF- $\alpha$ blockade is used in treatment of RA and had obvious efficacy. TNF- $\alpha$ blockade treatment for 3 months could decrease the expressed frequency of CD40L+CD4+ T cells in RA patients [38]. CD40L expression is transiently induced on $\mathrm{T}$ cell surface after activation. Lower $\mathrm{T}$ cell activation induced by TNF- $\alpha$ blockade treatment leads to lower CD40L expression. This effect may be secondary to decreased disease activity rather than due to the inhibitory effect of TNF- $\alpha$ blockade on $\mathrm{T}$ cell capacity to express CD40L [38] .
CD40L expression depends on $\mathrm{Ca}^{2+} / \mathrm{NFAT}$ signalling pathway. Increased $\mathrm{Ca}^{2+}$ influx as well as increased $\mathrm{Ca}^{2+}$ release-activated $\mathrm{Ca}^{2+}$ channel protein expression and function was observed in RA patients [39,40]. TNF- $\alpha$ blockade treatment in RA patients leads to inhibition of calcium influx which in turn leads to reduced CD40L [41]. This can explain our results that low SCD40L levels may be due to a decrease in calcium response due to treatment. Treatment could downregulate CD40L expression leaving other inflammatory molecules to play a key role in promoting a persistent inflammation $[\mathbf{3 8 , 4 2}]$. We cannot ascertain this finding through our study since RA patients without any type of treatment were not included in the study, which could represent a limitation.

\section{Conclusion:}

Our results suggest that polymorphism of premiRNA-146a rs2910164 gene is not associated with RA and does not increase the susceptibility to cardiovascular disease in the studied RA patients. The results also suggest that low concentrations of CD40L was detected in RA patients irrespective of the presence of cardiovascular risk. We recommend evaluating sCD40L in patients not receiving any treatment and comparing them with posttreatment levels.

Further studies are warranted with larger sample size to investigate whether polymorphisms of the pre-miRNA-146a rs2910164 gene and serum levels of SCD40L could represent a useful genetic biomarker for identifying Egyptian individuals with RA especially those at risk for cardiovascular disease development.

\section{Conflict of interest:}

Authors declare no conflict of interest.

\section{References}

1- ENGLAND B.R., THIELE G.M., ANDERSON D.R. and MIKULS T.R.: Increased cardiovascular risk in rheumatoid arthritis: Mechanisms and implications. BMJ, Apr. 23; 361: k1036. Doi: 10.1136/bmj.k1036, 2018.

2- NAKASA T., NAGATA Y., YAMASAKI K. and OCHI M.: A mini-review: microRNA in arthritis. Physiol Genomics, May 1; 43 (10): 566-70. Doi: 10.1152/ physiolgenomics.00142.2010, 2011.

3- SPARKS J.A.: Rheumatoid Arthritis. Ann. Intern. Med., Jan. 1; 170 (1): ITC1-ITC16. Doi: 10.7326/AITC 201901010, 2019.

4- BARTOLONI E., SHOENFELD Y. and GERLI R.: Inflammatory and autoimmune mechanisms in the induction of atherosclerotic damage in systemic rheumatic diseases: Two faces of the same coin. Arthritis Care Res (Hoboken). Feb., 63 (2): 178-83. doi: 10.1002/acr.20322, 2011. 
5- CAVAGNA L., BOFFINI N., CAGNOTTO G., INVERARDI F., GROSSO V. and CAPORALI R.: Atherosclerosis and rheumatoid arthritis: More than a simple association. Mediators Inflamm., 2012: 147354. Doi: 10.1155/2012/ 147354, 2012.

6- REISS A.B., SILVERMAN A., KHALFAN M., VERNICE N.A., KASSELMAN L.J., CARSONS S.E., et al.: Accelerated Atherosclerosis in Rheumatoid Arthritis: Mechanisms and Treatment. Curr. Pharm. Des., 25 9): 969-86. doi: 10.2174/1381612825666190430113212, 2019.

7- KARNELL J.L., RIEDER S.A., ETTINGER R. and KOLBECK R.: Targeting the CD40-CD40L pathway in autoimmune diseases: Humoral immunity and beyond. Adv. Drug Deliv. Rev., Feb. 15; 141: 92-103. doi: 10.1016/ j.addr.2018.12.005, 2019.

8- DAUB S., LUTGENS E., MÜNZEL T. and DAIBER A.: CD40/CD40L and Related Signaling Pathways in Cardiovascular Health and Disease-The Pros and Cons for Cardioprotection. Int. J. Mol. Sci., Nov. 12; 21 (22): 8533. doi: 10.3390/ijms21228533, 2020.

9- KOZERA L., ANDREWS J. and MORGAN A.W.: Cardiovascular risk and rheumatoid arthritis--the next step: Differentiating true soluble biomarkers of cardiovascular risk from surrogate measures of inflammation. Rheumatology (Oxford). Nov., 50 (11): 1944-54. doi: 10.1093/ rheumatology/ker232, 2011

10- EVANGELATOS G., FRAGOULIS G.E., KOULOURI V. and LAMBROU G.I.: MicroRNAs in rheumatoid arthritis: From pathogenesis to clinical impact. Autoimmun Rev., Nov., 18 (11): 102391. doi: 10.1016/ j.autrev.2019.102391, 2019.

11- SALVI V., GIANELLO V., TIBERIO L., SOZZANI S. and BOSISIO D.: Cytokine Targeting by miRNAs in Autoimmune Diseases. Front Immunol., Jan. 29; 10: 15. doi: 10.3389/fimmu.2019.00015, 2019.

12- ZHOU X., ZHU J., ZHANG H., ZHOU G., HUANG Y. and LIU R.: Is the microRNA-146a (rs2910164) polymorphism associated with rheumatoid arthritis? Association of microRNA-146a (rs2910164) polymorphism and rheumatoid arthritis could depend on gender. Joint Bone Spine, May; 82 (3): 166-71. doi: 10.1016/j.jbspin.2014.12.009, 2015.

13- HU Q., LI B., SHE R., WU X., TAN J., HU J., et al.: Association of polymorphisms of miR-146a rs 2910164 locus with clinical features of rheumatoid arthritis, May 10, 36 (5): 505-7. Chinese. doi: 10.3760/cma.j.issn.10039406.2019.05.023, 2019.

14- XIAO Y., LIU H., CHEN L., WANG Y., YAO X. and JIANG X.: Association of microRNAs genes polymorphisms with arthritis: A systematic review and metaanalysis. Biosci. Rep., Jul. 18, 39 (7): BSR20190298. doi: 10.1042/BSR20190298, 2019.

15- MAHARAJ A.B., NAIDOO P., GHAZI T., ABDUL N.S., DHANI S., DOCRAT T.F., et al.: MiR-146a G/C rs2910164 variation in South African Indian and Caucasian patients with psoriatic arthritis. BMC Med. Genet., Mar. 27; 19 (1): 48. doi: 10.1186/s12881-018-0565-1, 2018.

16- LU L.F. and LISTON A.: MicroRNA in the immune system, microRNA as an immune system. Immunology, Jul., 127 (3): 291-8. doi: 10.1111/j.1365-2567.2009. 03092.x, 2009.
17- LÖFGREN S.E., FROSTEGÅRD J., TRUEDSSON L., PONS-ESTEL B.A., D'ALFONSO S., WITTE T., et al.: Genetic association of miRNA-146a with systemic lupus erythematosus in Europeans through decreased expression of the gene. Genes Immun., Apr., 13 (3): 268-74. doi: 10.1038/gene.2011.84, 2012.

18- HASHEMI M., ESKANDARI-NASAB E., ZAKERI Z., ATABAKI M., BAHARI G., JAHANTIGH M., et al.: Association of pre-miRNA-146a rs2910164 and pre miRNA-499 rs3746444 polymorphisms and susceptibility to rheumatoid arthritis. Mol. Med. Rep., Jan., 7 (1): 287 91. doi: 10.3892/mmr.2012.1176, 2013.

19- JI J.D., CHA E.S. and LEE W.J.: Association of miR146a polymorphisms with systemic lupus erythematosus: A meta-analysis. Lupus, Sep., 23 (10): 1023-30. doi: 10.1177/0961203314534512, 2014.

20- FU L., JIN L., YAN L., SHI J., WANG H., ZHOU B., et al.: Comprehensive review of genetic association studies and meta-analysis on miRNA polymorphisms and rheumatoid arthritis and systemic lupus erythematosus susceptibility. Hum. Immunol., Jan., 77 (1): 1-6. doi: 10.1016/ j.humimm.2014.09.002, 2016.

21- FUNOVITS J., ALETAHA D., BYKERK V., COMBE B., DOUGADOS M., EMERY P., et al.: The 2010 American College of Rheumatology/European League Against Rheumatism classification criteria for rheumatoid arthritis: Methodological Report Phase IAnnals of the Rheumatic Diseases, 69: 1589-95, 2010.

22- PREVOO M.L., VAN 'T HOF M.A., KUPER H.H., VAN LEEUWEN M.A., VAN De PUTTE L.B. and VAN RIEL P.L.: Modified disease activity scores that include twentyeight-joint counts. Development and validation in a prospective longitudinal study of patients with rheumatoid arthritis. Arthritis Rheum., Jan., 38 (1): 44-8. doi: 10.1002/ art.1780380107, 1995.

23- DAWSON B. and TRAPP R.G.: Basic \& Clinical Biostatistics, Lange Medical Book/McGraw-Hill, Medical Publishing Division. 3 rd ed. Ch. 7-9, PP. 161-218, 2001.

24- ZHOU S.S., JIN J.P., WANG J.Q., ZHANG Z.G., FREEDMAN J.H., ZHENG Y., et al.: miRNAS in cardiovascular diseases: Potential biomarkers, therapeutic targets and challenges. Acta Pharmacol. Sin., Jul., 39 (7): 1073-84. doi: 10.1038/aps.2018.30, 2018.

25- YANG B., ZHANG J.L., SHI Y.Y., LI D.D., CHEN J., HUANG Z.C., et al.: Association study of single nucleotide polymorphisms in pre-miRNA and rheumatoid arthritis in a Han Chinese population. Mol. Biol. Rep., Nov., 38 (8): 4913-9. doi: 10.1007/s11033-010-0633-x, 2011.

26- AYELDEEN G., NASSAR Y., AHMED H., SHAKER O. and GHEITA T.: Possible use of miRNAs-146a and -499 expression and their polymorphisms as diagnostic markers for rheumatoid arthritis. Mol. Cell. Biochem., Dec., 449 (1-2): 145-56. doi: 10.1007/s11010-018-3351-7, 2018.

27- LAI X., WANG H., CAO J., LI Y., DAI Y., XIANG Y., et al.: Circulating IL-27 is elevated in rheumatoid arthritis patients. Molecules, 21 (11): E1565, 2016.

28- ALEMÁN-ÁVILA I., JIMÉNEZ-MORALES M., BELTRÁN-RAMÍREZ O., BARBOSA-COBOS R.E., JIMÉNEZ-MORALES S., SÁNCHEZ-MUÑOZ F., et al.: Functional polymorphisms in pre-miR146a and pre-miR499 are associated with systemic lupus erythematosus but not 
with rheumatoid arthritis or Graves' disease in Mexican patients. Oncotarget., Jul. 27, 8 (54): 91876-91886. doi: 10.18632/oncotarget.19621, 2017.

29- EL-SHAL A.S., ALY N.M., GALIL S.M., MOUSTAFA M.A. and KANDEL W.A.: Association of microRNAs genes polymorphisms with rheumatoid arthritis in Egyptian female patients. Joint Bone Spine, Dec., 80 (6): 626-31. doi: 10. 10 16/j.jbspin.2013.03.005, 2013.

30- WANG D. and PAN G.: Association of rs2910164 Polymorphism in miRNA-146 and rs3746444 Polymorphism in miRNA-499 with Inflammatory Arthritis: A MetaAnalysis. Biomed. Res. Int., May 16; 2019: 7305750. doi: 10.1155/2019/7305750, 2019.

31- AHMADI K., SOLEIMANI A., SOLEIMANI MOTLAGH S., BAHARVAND AHMADI S., ALMASIAN M. and KIANI A.A.: Polymorphisms of Pre-miR-499 rs3746444 T/C and Pre-miR-146a rs2910164 C/G in the Autoimmune Diseases of Rheumatoid Arthritis and Systemic Lupus Erythematosus in the West of Iran. Iran J. Public Health, Apr., 49 (4): 782-90, 2020.

32- LIU M.F., CHAO S.C., WANG C.R. and LEI H.Y.: Expression of CD40 and CD40 ligand among cell populations within rheumatoid synovial compartment. Autoimmunity, 34 (2): 107-13. doi: 10.3109/08916930109001958, 2001.

33- TAMURA N., KOBAYASHI S., KATO K., BANDO H., HARUTA K., OYANAGI M., et al.: Soluble CD154 in rheumatoid arthritis: Elevated plasma levels in cases with vasculitis. J. Rheumatol, Dec., 28 (12): 2583-90, 2001.

34- ROMÁN-FERNÁNDEZ I.V., GARCÍA-CHAGOLLÁN M., CERPA-CRUZ S., JAVE-SUÁREZ L.F., PALAFOXSÁNCHEZ C.A., GARCÍA-ARELLANO S., et al.: Assessment of CD40 and CD40L expression in rheumatoid arthritis patients, association with clinical features and DAS28. Clin. Exp. Med., Nov., 19 (4): 427-37. doi: 10.1007/s10238-019-00568-5, 2019.

35- PRAHALAD S., MARTINS T.B., TEBO A.E., WHITING A., CLIFFORD B., ZEFT A.S., et al.: Elevated serum levels of soluble CD154 in children with juvenile idiopathic arthritis. Pediatr. Rheumatol. Online J., May 28, 6: 8. doi: 10.1186/1546-0096-6-8, 2008.

36- ROUBILLE C., RICHER V., STARNINO T., McCOURT
C., McFARLANE A., FLEMING P., et al.: The effects of tumour necrosis factor inhibitors, methotrexate, nonsteroidal anti-inflammatory drugs and corticosteroids on cardiovascular events in rheumatoid arthritis, psoriasis and psoriatic arthritis: A systematic review and metaanalysis. Ann. Rheum. Dis., Mar., 74 (3): 480-9. doi: 10. 113 6/annrheumdis-2014-206624, 2015.

37- KIM S.C., SOLOMON D.H., LIU J., FRANKLIN J.M., GLYNN R.J. and SCHNEEWEISS S.: Risk of venous thromboembolism in patients with rheumatoid arthritis: Initiating disease-modifying antirheumatic drugs. Am. J. Med., May, 128 (5): 539.e7-17. doi: 10.1016/j.amjmed. 2014.11.025, 2015.

38- TUNG C.H., LU M.C., LAI N.S. and WU S.F.: Tumor necrosis factor-a blockade treatment decreased CD154 (CD40-ligand) expression in rheumatoid arthritis. PLoS One, Aug. 24, 12 (8): e0183726. doi: 10.1371/journal.pone. 0183726, 2017.

39- LOWE R.M., GENIN A., ORGUN N. and CRON R.Q.: IL-15 prolongs CD154 expression on human CD4 T cells via STAT5 binding to the CD154 transcriptional promoter. Genes Immun., Apr.-May, 15 (3): 137-44. doi: 10.1038/ gene.2014.3, 2014.

40- LIU S., WATANABE S., SHUDOU M., KUNO M., MIURA H. and MAEYAMA K.: Upregulation of storeoperated $\mathrm{Ca}(2+)$ entry in the naïve CD4(+) T cells with aberrant cytokine releasing in active rheumatoid arthritis. Immunol. Cell Biol., Oct., 92 (9): 752-60. doi: 10.1038/ icb.2014.45, 2014.

41- SZALAY B., CSEH A., MÉSZÁROS G., KOVÁCS L., BALOG A. and VÁSÁRHELYI B.: The impact of DMARD and anti-TNF therapy on functional characterization of short-term T-cell activation in patients with rheumatoid arthritis--a follow-up study. PLoS One, Aug. 6; 9 (8): e104298. doi: 10.1371/journal.pone.0104298, 2014.

42- WU S.F., CHANG C.B., HSU J.M., LU M.C., LAI N.S., LI C., et al.: Hydroxychloroquine inhibits CD154 expression in CD4+ T lymphocytes of systemic lupus erythematosus through NFAT, but not STAT5, signaling. Arthritis Res. Ther., Aug. 9, 19 (1): 183. doi: 10.1186/s13075-0171393-y, 2017. 


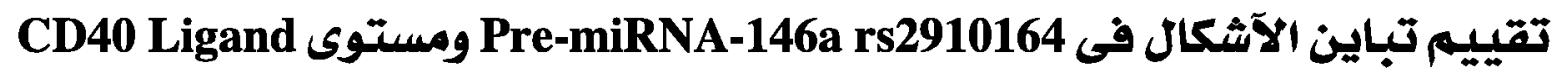 في المرضى الإئ فصريين المصابين بإلتهاب المفاصل الروماتويلىى}

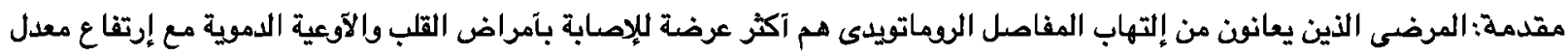

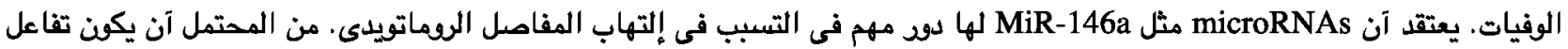

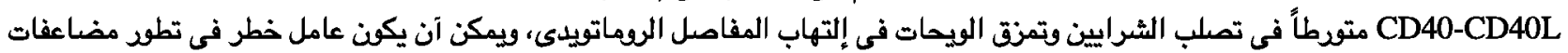
الآوعية الدموية لدى المرضى.

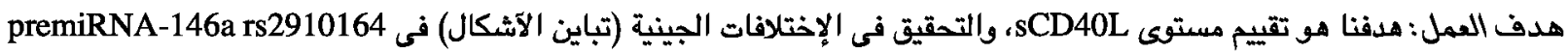

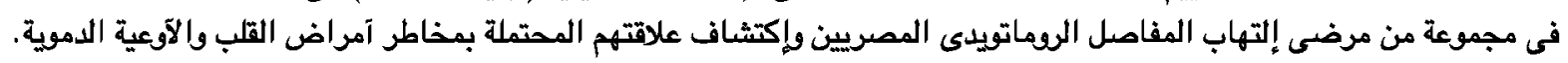

الطريقة: تم تسجيل ^ ـ 1 مرضى إلتهاب المفاصل الروماتويدى فى دراستتا وتم تقسيمه إلى مجموعتين ونقاً لوجود وغياب مخاطر آمراض

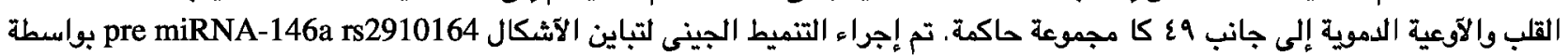
SCD40L ELISA ومستويات TaqMan real-time PCR

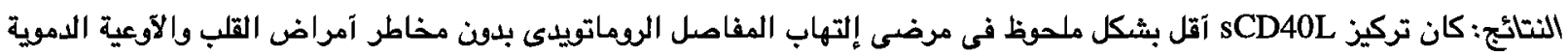

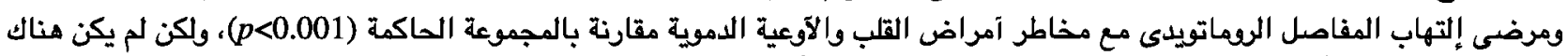

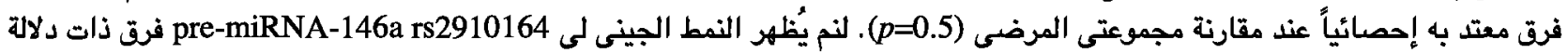

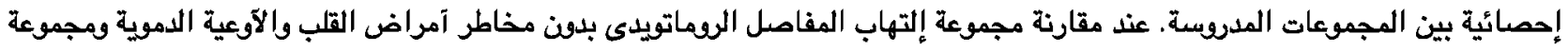

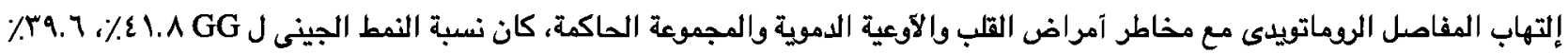

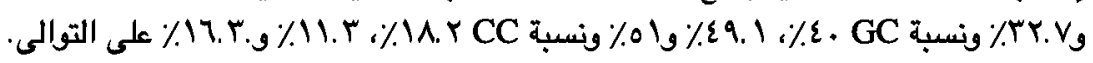

الملخص: لم تكن الإختلافات الجينية pre-miRNA-146a rs2910164 مرتبطة بمرض إلتهاب المفاصل الروماتويدى ولا تزيد من قابلية

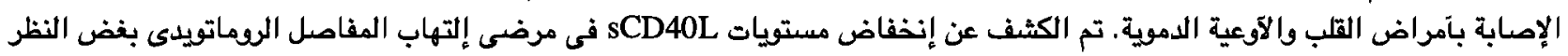

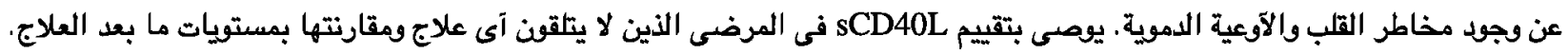

